\title{
Course Evaluation Based on Workshop Teaching
}

\author{
Huiqing $\mathrm{Li}^{\mathrm{a}}$, Aihua Deng ${ }^{\mathrm{b}}$ \\ Shenzhen Polytechnic, Shenzhen 518055, China. \\ a596048283@qq.com, bdengaihua@szpt.edu.cn
}

Keywords: workshop, course evaluation, evaluation index, evaluation standard.

\begin{abstract}
During workshop teaching, courses are learnt through solving specific issues, it becomes one of the important teaching modes of vocational education thanks to its high degree of participation in teaching activities, and previous course evaluation systems are no longer applicable to workshop teaching. This paper firstly introduces characteristics of workshop teaching mode, and then provides indexes of course evaluation and student evaluation of workshop teaching and evaluation information collecting points corresponding to such indexes, and then gives evaluation standards based on teaching activities.
\end{abstract}

\section{Introduction}

Workshop is applied to vocational education in recent years, courses are learnt through solution of single or a series of specific issues, and it becomes one of the important teaching modes of higher vocational education thanks to its high degree of participation during teaching. Compared with traditional teaching modes, workshop teaching is obviously changed.

Interactive modes of courses are changed. Workshop teaching changes interactive mode between teachers and students, between students and students and between students and contents of courses. It is changed from teachers' lecturing and students' listening in the previous time to teachers' coaching and students' speaking and doing at present; it is changed from teacher's one-to-many to many-to-many among teachers, students and other participants in the course; interaction between students and learnt contents also becomes real-time, dynamic, diversified and deeper. Questioning and rethinking develop simultaneously, exploration and summarization exist together.

Knowledge sourcing channels are changed. Traditional priorities given to teachers and teaching materials are changed in workshop teaching. Teachers, through meticulous design, may arrange students to make preparations in advance, invite students' parents, professional personnel of the same industry, previous graduates or senor fellow apprentices at school to participate jointly. So contents to be learnt are sourced from teachers, students and other participants, and the workshop integrates and shares information from all parties organically.

Information processing mode is changed. Traditional teachers are processors and transmitters of information which is thoroughly changed in workshop teaching. Each participant in the workshop is the processor, transmitter and receiver of information. In the entire process, information is fully collected, deeply processed and becomes sweet memory of each participant.

Action-orientation, knowledge and action becoming one are fully reflected. In the group atmosphere, which let each student speak and let each student do, knowledge is compared, rethought and constructed while speaking and doing, and skills are internalized. Workshop teaching makes conceptual work become collective activity, study, information, knowledge, actions, emotions and values of individuals are linked organically during interaction under stimulation of group mechanism, and psychological construction is promoted while construction of knowledge.

Workshop teaching brings vitality and tension to vocational education courses, and such changes also request to make adjustments to corresponding course evaluation system.

People's actions are like flowing water, which will flow to the easiest direction nearby under free selection. For teaching activities, courses are more like rivers and course evaluation is the dam. Zhong Qiquan defines course evaluation as following: course evaluation is the process of collecting and 
providing evidences to make value judgment according to implementation possibility, effectiveness and education value of courses, which contains two aspects, the first aspect is the judgment of planning and organization of education process, and the second aspect is the judgment of students' achievements (study results of students). As the basic loop of teaching activities, course evaluation has functions of orientation, diagnosis, decision-making and development promotion. Course evaluation based on workshop teaching places particular emphasis on implementation process and implementation results of courses.

\section{Course evaluation indexes}

Course evaluation indexes based on workshop teaching shall lay extra emphasis on students' degree of participation, openness, divergence, collaboration and enjoyment in the course.

Degree of participation of the course directly affects teaching effect of the course. One course is half successful once it is able to catch students' eyes and hearts and make good use of students' mouths and hands. Therefore, degree of participation in the course is the first index. Students' involving in the course with heart and soul will be definitely extended to the time before and after class, and it can be named as course irradiance. People's devotion to their career depends on their involvement load, and much course involvement of students will make students lose their hearts to corresponding course.

Openness of course determines vitality and elasticity of teaching activities, and it is reflected in openness of teaching resources, openness of teaching process and openness of teaching achievements. Workshop is originally a way and method solving social problems and design problems by using openness. When it is applied in course teaching, sources of course information are not limited to books and teachers, the place of course can be classrooms, studios, work sites, scenes and other suitable places, technicians of the industry, parents, senior fellow apprentices and others may be invited to participate in teaching, and the direct teaching result may be the proposal drawn on the wisdom of the masses or chart data or modeling of material objects.

The emphasis of vocational education activity is solving specific issues, therefore, traditional teaching gives prominence to key points, the way to solve problems is sole, contents before and after are linked in series, and rapid convergence is the pursuit.It is favorable to fast maturity of students' professional skills but unfavorable to cultivation of divergent thinking and forming of innovation and creation consciousness, and the teaching efficiency is lower. Workshop teaching adopts the way of dispersed investigation and survey, concentrated research and discussion and problem solving by grouping. In this case, the original materials are diversified, plans solving problems are multiple, ways and methods are multiple, obvious achievements are multiple, teaching contents are presented in parallel, and solutions are brought out in parallel, compare - choose — rethink. Therefore, divergence and parallelism are considered as evaluation indexes of workshop teaching. In case workshop obtains consistent conclusion quickly, such teaching activity is unsuccessful.

Workshop provides a kind of situation for cooperative learning. Active emotion in the group provides a kind of pleasant environment which is able to inspire more vitality. In fact, learning efficiency of the group full of cohesive force is higher than the same number of individuals. In the meanwhile, everyone is respected and concerned thanks to the way of "encouraging behaviors and judging works" adopted by the workshop, self-centeredness is reduced and individual accountability is enhanced. Thus, collaboration index of the course becomes especially important.

Enjoyment design of the course will make it charming, and its promotion to degree of participation, openness, divergence and collaboration cannot be underestimated. Enjoyment will make hard knowledge soft, numerous information colorful, ice-cold operation procedures warm, and the other side of enjoyment is creativity. Enjoyment design of workshop teaching can mobilize all participants during workshop teaching to design enjoyment of next time as one of the contents of workshop after current course is finished. 


\section{Student evaluation indexes}

Student evaluation indexes based on workshop teaching include ability of analysis and summarization, problem-solving ability, teamwork ability, innovation and creation consciousness and imagination.

Due to the wide sources and multiple channels of workshop information, ways and methods to solve problems are brought forward from each angle and each layer. Divergence of the course cultivates students' parallel thinking, make students' view broader, and provides more searching space when facing emergent problems, but choosing solutions in short time and the ability of analysis and summarization are the most basic competence of workshop teaching.

Workshop teaching confronts one special issue each time. First of all, relevant information is shared in the entire class; and opinions are expressed in each group to put forward solutions and form resolutions of each group; then solutions of each small group are questioned by the entire class and rethought; finally, proposals are implemented to achieve implementation results, the entire class summarizes experience of success and analyzes reasons of failure. Workshop teaching firstly cultivates habit of students facing problems directly, secondly makes students master routes of solving problems and thirdly extends antennas of students to solve problems. Each person may be considered as a control system which is able to make a series of actions and correct through feedback. Thus, practical courses are especially important in vocational education and operation is not only to master skills, but also to reach and learn problem-solving ability from practical results. Problem-solving ability is the core index of vocational education and the important index to evaluate students.

During implementation of workshop teaching, students are divided into groups to finish the initial plans to solve problems within groups, and each member must propose their own opinions which cannot be questioned and criticized but can only be encouraged and supported by other members, and all speeches are combined into the group's proposal. All groups shall preach their own proposals, accept questioning and criticism from other groups and shall improve their own proposals. Right now, each person is requested to find out mistakes or loopholes of other groups' proposals. And then proposals are implemented to obtain practical results. At this moment, all workshop participants shall appraise each practical result and elect the best achievements. The entire process above-mentioned is the process of collaborative learning, teamwork always runs through the entire workshop teaching. Thus, promotion of teamwork ability is the third index of student evaluation in workshop teaching.

Workshop teaching fulfills students' knowledge construction and psychological construction through solution of concrete issues. Problem solving needs innovation and creation consciousness, and problem solving will drive innovation and creation consciousness. In fact, same as aesthetic consciousness, creation activities are part of daily life and leisure life. Any change or improvement can be considered innovation. Start from drops and many a little makes a mickle. Workshop encourages changes, unrestrained and vigorous style that brims with talents, and all kinds of idea combinations, which creates the atmosphere getting new ideas and new approaches at any time, and forms an environment generating creativity based on cohesive force of collectivity. Considering innovation consciousness as index of student evaluation is just the utilization of evaluation orientation.

As the carrier of internalized knowledge, imagination is inherent ability, and enjoyment does not make any sense without imagination. Workshop teaching activities attempt to make use of imagination to link knowledge, skills, emotions, values and creativity, thus it is also the index of student evaluation.

\section{Distribution of evaluation points}

Since workshop learns by solving specific issues collectively, workshop teaching activities are divided into stages.

Stage one is conducted before and after class. Students are arranged to collect similar cases or relevant experience and knowledge from multi-channels, multi-layers and multi-angles as much as 
possible to guarantee openness and divergence of contents. At the beginning, teachers may distribute different cases or designate relevant resources for students to collect. Collected materials shall be classified and kept by group/person.

In stage two, materials are shared in the group to discuss problem-solving methods, each person comes up with their own opinions which shall not be interrupted, questioned and judged by others, the more the better, and all opinions shall be recorded. Then, opinions of everyone are summarized and prepared into problem-solving proposal of the group. Each person shall make records once at least which will be considered as one of the contents of assessment. Group members shall confirm and sign on records as evaluation materials.

Stage three is brainstorm. Each group shall appoint one person to preach their own proposal and accept other groups finding faults and mistakes, and recorder of the group shall record questions as the basis to modify their own proposal. Right now, each group shall mark and rank each speaker, and shall rank each question and criticism according to their own value judgment.

Stage four is organization and implementation. Each group carries out their proposals to form practical achievements, which are the concern of evaluation undoubtedly. Group members shall record process of implementation, division of labor and details of participation.

Stage five is achievement evaluation. Firstly, everyone shall find out advantages of each achievement in turn, and then change their thoughts and find out disadvantages of each achievement, and each group shall complete mission summarization.

Stage six is entire evaluation of the workshop, and questionnaire is mainly adopted. Detailed questions are as following: (1) What are you satisfied most for yourself in such workshop activity? What improvements do you have? (2) What are you interested most in such activity? What is the most unsatisfying? (3) Which group's achievement do you like best, where do you think it can be applied? (4) What do you think are the most creative opinions and suggestions or works in such activity?

Stage seven is conclusion evaluation. Such stage is equivalent to examination in the last stage of the course, and students may be requested to answer comprehensive questions or finish comprehensive tasks independently.

\section{Evaluation standards}

Evaluation standards shall be clarified after evaluation indexes and evaluation points are confirmed, please refer to table 1 .

Table 1 Evaluation Standards

\begin{tabular}{|c|c|c|c|c|c|c|}
\hline \multirow[t]{2}{*}{ Stage } & \multirow[t]{2}{*}{ Task } & \multirow[t]{2}{*}{ Activities } & \multirow{2}{*}{$\begin{array}{l}\text { Evaluation } \\
\text { points }\end{array}$} & \multicolumn{2}{|c|}{$\begin{array}{c}\text { Evaluation indexes corresponding to } \\
\text { evaluation points }\end{array}$} & \multirow[t]{2}{*}{ Evaluation standards } \\
\hline & & & & Courses & Students & \\
\hline Stage 1 & $\begin{array}{l}\text { Information } \\
\text { collection }\end{array}$ & $\begin{array}{l}\text { Collect similar } \\
\text { cases or } \\
\text { relevant } \\
\text { experience }\end{array}$ & $\begin{array}{l}\text { Quantity and } \\
\text { quality of } \\
\text { collected } \\
\text { materials }\end{array}$ & $\begin{array}{l}\text { Openness, } \\
\text { divergence } \\
\text { and degree of } \\
\text { participant of } \\
\text { the course }\end{array}$ & $\begin{array}{l}\text { Students' ability of } \\
\text { collecting and processing } \\
\text { information }\end{array}$ & $\begin{array}{l}\text { It is excellent if collected materials are } \\
\text { complete with high quality and have high } \\
\text { degree of association with the project; it } \\
\text { is good if collected materials are } \\
\text { complete and quality is good; it is } \\
\text { medium if completed materials are } \\
\text { complete; and it is poor in case there are } \\
\text { few collected materials. }\end{array}$ \\
\hline Stage 2 & $\begin{array}{l}\text { Group } \\
\text { proposal } \\
\text { preparation }\end{array}$ & $\begin{array}{l}\text { Share } \\
\text { materials and } \\
\text { complete } \\
\text { group's } \\
\text { proposal. }\end{array}$ & $\begin{array}{l}\text { Quantity and } \\
\text { quality of } \\
\text { students' ideas } \\
\text { when } \\
\text { proposals are } \\
\text { formed. }\end{array}$ & $\begin{array}{l}\text { Openness, } \\
\text { divergence, } \\
\text { degree of } \\
\text { participation, } \\
\text { collaboration } \\
\text { and } \\
\text { enjoyment of } \\
\text { the course }\end{array}$ & $\begin{array}{l}\text { Students' ability of analysis } \\
\text { and summarization, } \\
\text { problem-solving ability, } \\
\text { teamwork ability, } \\
\text { innovation and creation } \\
\text { consciousness and } \\
\text { imagination }\end{array}$ & $\begin{array}{l}\text { It is excellent if students have many } \\
\text { ideas, high quality proposals and highly } \\
\text { associated with the project; it is good if } \\
\text { there are many ideas and the quality is } \\
\text { good; it is medium if there are many } \\
\text { ideas; and it is poor if there are few ideas } \\
\text { and proposals. }\end{array}$ \\
\hline Stage 3 & $\begin{array}{l}\text { Research and } \\
\text { discussion of } \\
\text { proposal }\end{array}$ & $\begin{array}{l}\text { Listen to } \\
\text { questioning of } \\
\text { other groups }\end{array}$ & $\begin{array}{l}\text { Quantity and } \\
\text { quality of } \\
\text { students' }\end{array}$ & $\begin{array}{l}\text { Openness, } \\
\text { divergence, } \\
\text { degree of }\end{array}$ & $\begin{array}{l}\text { Students' ability of analysis } \\
\text { and summarization, } \\
\text { problem-solving ability, }\end{array}$ & $\begin{array}{l}\text { During proposal research and discussion, } \\
\text { it is excellent if there are many high } \\
\text { quality questions from other groups; it is }\end{array}$ \\
\hline
\end{tabular}




\begin{tabular}{|c|c|c|c|c|c|c|}
\hline & & $\begin{array}{l}\text { and improve } \\
\text { the proposal. }\end{array}$ & $\begin{array}{l}\text { questioning } \\
\text { during } \\
\text { proposal } \\
\text { research and } \\
\text { discussion }\end{array}$ & $\begin{array}{l}\text { participation, } \\
\text { collaboration } \\
\text { and } \\
\text { enjoyment of } \\
\text { the course }\end{array}$ & $\begin{array}{l}\text { teamwork ability, } \\
\text { innovation and creation } \\
\text { consciousness and } \\
\text { imagination }\end{array}$ & $\begin{array}{l}\text { good if there are many good quality } \\
\text { questions; it is medium if there are many } \\
\text { questions; and it is poor if there are few } \\
\text { questions. }\end{array}$ \\
\hline Stage 4 & $\begin{array}{l}\text { Proposal } \\
\text { implementation }\end{array}$ & $\begin{array}{l}\text { Implement } \\
\text { proposal and } \\
\text { form practical } \\
\text { achievements }\end{array}$ & $\begin{array}{l}\text { Quality of } \\
\text { group's } \\
\text { achievements }\end{array}$ & $\begin{array}{l}\text { Openness, } \\
\text { divergence, } \\
\text { degree of } \\
\text { participation, } \\
\text { collaboration } \\
\text { and } \\
\text { enjoyment of } \\
\text { the course }\end{array}$ & $\begin{array}{l}\text { Students' ability of analysis } \\
\text { and summarization, } \\
\text { problem-solving ability, } \\
\text { teamwork ability, } \\
\text { innovation and creation } \\
\text { consciousness and } \\
\text { imagination }\end{array}$ & $\begin{array}{l}\text { It is excellent if proposals are carried out } \\
\text { and high quality achievements are } \\
\text { obtained; it is good if quality is good; it is } \\
\text { medium if quality is normal, and it is } \\
\text { poor if quality is bad. }\end{array}$ \\
\hline Stage 5 & $\begin{array}{l}\text { Achievements } \\
\text { evaluation }\end{array}$ & $\begin{array}{l}\text { Find out } \\
\text { advantages } \\
\text { and } \\
\text { disadvantages } \\
\text { of } \\
\text { achievements } \\
\text { of each group, } \\
\text { group } \\
\text { summarization }\end{array}$ & $\begin{array}{l}\text { Quality of } \\
\text { group project } \\
\text { summarization }\end{array}$ & $\begin{array}{l}\text { Openness, } \\
\text { divergence, } \\
\text { degree of } \\
\text { participation, } \\
\text { collaboration } \\
\text { and } \\
\text { enjoyment of } \\
\text { the course }\end{array}$ & $\begin{array}{l}\text { Students' ability of analysis } \\
\text { and summarization, } \\
\text { problem-solving ability, } \\
\text { teamwork ability, } \\
\text { innovation and creation } \\
\text { consciousness and } \\
\text { imagination }\end{array}$ & $\begin{array}{l}\text { It is excellent is the project is } \\
\text { summarized completely with high } \\
\text { quality; it is good if summarization is } \\
\text { complete and quality is good; it is } \\
\text { medium if summarization is complete } \\
\text { and quality is normal; it is poor if } \\
\text { summarization is incomplete and quality } \\
\text { is normal. }\end{array}$ \\
\hline Stage 6 & $\begin{array}{l}\text { Collective } \\
\text { evaluation }\end{array}$ & $\begin{array}{l}\text { Complete } \\
\text { evaluation } \\
\text { questionnaire }\end{array}$ & $\begin{array}{l}\text { Contents of } \\
\text { questionnaire }\end{array}$ & $\begin{array}{l}\text { Openness, } \\
\text { divergence, } \\
\text { degree of } \\
\text { participation, } \\
\text { collaboration } \\
\text { and } \\
\text { enjoyment of } \\
\text { the course }\end{array}$ & $\begin{array}{l}\text { Students' ability of analysis } \\
\text { and summarization, } \\
\text { problem-solving ability, } \\
\text { teamwork ability, } \\
\text { innovation and creation } \\
\text { consciousness and } \\
\text { imagination }\end{array}$ & $\begin{array}{l}\text { Design of questionnaire is aimed at } \\
\text { different indexes, and teachers shall } \\
\text { assess according to the purpose and } \\
\text { responses of students. }\end{array}$ \\
\hline Stage 7 & $\begin{array}{l}\text { Final } \\
\text { evaluation }\end{array}$ & $\begin{array}{l}\text { Complete } \\
\text { comprehensive } \\
\text { questions or } \\
\text { comprehensive } \\
\text { project }\end{array}$ & $\begin{array}{l}\text { Results of } \\
\text { comprehensive } \\
\text { questions or } \\
\text { project }\end{array}$ & $\begin{array}{l}\text { Openness, } \\
\text { divergence, } \\
\text { degree of } \\
\text { participation, } \\
\text { collaboration } \\
\text { and } \\
\text { enjoyment of } \\
\text { the course }\end{array}$ & $\begin{array}{l}\text { Students' ability of analysis } \\
\text { and summarization, } \\
\text { problem-solving ability, } \\
\text { teamwork ability, } \\
\text { innovation and creation } \\
\text { consciousness and } \\
\text { imagination }\end{array}$ & $\begin{array}{l}\text { Answering of comprehensive questions } \\
\text { or practice of comprehensive projects is } \\
\text { inspection of effect of entire teaching } \\
\text { activity, and it shall be assessed } \\
\text { comprehensively according to teachers } \\
\text { and others involved }\end{array}$ \\
\hline
\end{tabular}

\section{Conclusions}

Course evaluation based on workshop teaching remains screening and selection functions of evaluation, but places more emphasis on motivation and development functions of evaluation. Students reserve all achievement materials as a group, which record development and progress of students. Students know themselves, find themselves, appreciate themselves and development themselves through workshop teaching activities.

Course evaluation points and forms based on workshop teaching are diversified, and they pay attention to generality and emphasize individual difference. It promotes group progress and supports individual development. It fully guarantees and reflects collaboration of teaching activities.

Distributed in teaching process at real time, course evaluation based on workshop teaching is convenient to trace, regulate and control course teaching and evaluation, and it guarantees degree of participation and interactive effect of teaching activities.

Course evaluation based on workshop teaching realizes multi-subject evaluation, which means that teachers and students pay dual roles in the process of evaluation, course construction and development are promoted jointly, and course resources are enriched constantly and interactive ways are innovated continuously. 
Course evaluation based on workshop teaching takes qualitative evaluation as the core, and quantitative evaluation to supplementary, and the process of evaluation is open. Teaching activities and evaluation activities are synchronous and interactive.

In addition, there are several problems, which need to be solved further. For example, course evaluation based on workshop teaching increases teachers' workload, and professional technicians and students' parents have the passion to participate once or twice, but it is difficult for them to participate many times. It is only feasible to guarantee the workshop teaching effect in the mechanism or economy.

\section{References}

[1] Zhong Qiquan. Modern Curriculum Theory. Shanghai: Shanghai Education Press, 1989: 348.

[2] Lu Changping. Construction of Inquiry Teaching Course Index Evaluation System , J. China University Education, 2013 (6), 76-88.

[3] Li Yanbing. Evaluation and Research of Qualitative Courses, D. East China Normal University, 2000: 17.

[4] Bruce Joyce, Marsha Well, Emily Calhoun. Model of Teaching . Beijing: China Light Industry Press, 2009, 108-109.

[5] Pang Xiaoqing. Problems Existing in Course Evaluation and Improvement Strategies, J. Kaifeng Education College Newspaper, 2013 (3) 63-65.

[6] Li Yanbing. Course Evaluation Theory . Shanghai: Shanghai Education Press, 2002: 203-204. 